\title{
"Os saraus são as bibliotecas sonoras das periferias": uma narrativa sobre letramentos e o direito à cidade
}

DOI: https://doi.org/10.22409/pragmatizes.v11i20.45797

\section{Adriana Carvalho Lopes ${ }^{1}$ Janaina Tavares ${ }^{2}$}

\begin{abstract}
Resumo: As produções culturais periféricas, além de serem uma opção de lazer, de produção, de trabalho e de participação político-cultural para as juventudes periféricas, podem ser entendidas como uma poderosa agência de letramento (KLEIMAN, 1995). Fundamentadas pela nossa experiência em um sarau periférico, chamado Sarau $V$ (de Viral), realizado na cidade de Nova Iguaçu, região metropolitana do estado do Rio de Janeiro, idealizado e organizado pela coautora Janaina Tavares; tecemos uma narrativa constituída por uma 'dupla autoria' em dois gêneros textuais distintos (BAKHTIN, 1997), que chamamos de escrita-cena e de escrita-bastidor (GOFFMAN,1985). Fundamentadas pelo campo de estudos dos letramentos (STREET, 2001), argumentamos que as práticas do sarau evidenciam uma escrita multissemiótica e multissensória (MILLS, 2016) que desnaturaliza as projeções escalares hegemônicas (CARR; LEMPERT, 2016), reterritorializa espaços urbanos (GUATTARI; ROLNIK, 2010) e reivindica o direito à cidade (HARVEY, 2016).
\end{abstract}

Palavras-chave: Letramentos; juventudes periféricas; direito à cidade.

"Los saraos son las bibliotecas sonoras de las periferias": una narrativa sobre letramientos y el derecho a la ciudad

Resumen: Las producciones culturales periféricas, además de ser una opción de recreo, producción, trabajo y participación político-cultural para los jóvenes periféricos, pueden entenderse como una poderosa agencia de letramiento (KLEIMAN, 1995). A partir de nuestra experiencia en una velada periférica, denominada Sarau V (Viral), realizada en la ciudad de Nova Iguaçu, región metropolitana del estado de Río de Janeiro, idealizada y organizada por Janaina Tavares, una de las autoras de este texto, tejemos una narrativa por una "doble autoría" en dos géneros textuales distintos (BAKTHIN, 1997), que llamamos escritura de escena y escritura de fondo (GOFFMAN, 1985). Partiendo del campo de los estudios de letramiento (STREET, 2001), argumentamos que las prácticas do Sarau V muestran una escritura multisemiótica y multisensorial (MILLS, 2016) que

\footnotetext{
${ }^{1}$ Adriana Carvalho Lopes. Doutora em Linguística pela Universidade de Campinas. Professora de Departamento de Educação e Sociedade do Instituto Multidisciplinar da Universidade Federal Rural do Rio de Janeiro (IM/UFRRJ). Professora do Programa de Pós-Graduação em Educação e Demandas Populares - PPGDUC/UFRRJ e do Programa Interdisciplinar de Pós-Graduação em Linguística Aplicada da Universidade Federal do Rio de Janeiro (PIPGLA/UFRJ), Brasil. E-mail: adrianaclopes14@gmail.com - https://orcid.org/ 0000-0002-6068-8308

2 Janaina Tavares. Mestranda no Programa Interdisciplinar de Pós-Graduação em Linguística Aplicada da Universidade Federal do Rio de Janeiro - PIPGLA/UFRJ, Brasil. E-mail: janaa.tavaresv@gmail.com - https://orcid.org/0000-02-8436-4842
} 
desnaturaliza las proyecciones escalares hegemónicas (CARR; LEMPERT, 2016), reterritorializa los espacios urbanos (GUATTARI; ROLNIK, 2010) y reivindica el derecho a la ciudad (HARVEY, 2016).

Palabras clave: Letramientos; juventud periférica; derecho a la ciudad.

"The soirées are the sound libraries of the peripheries": A narrative about literacies and the right to the city

Abstract: Peripheral cultural productions, in addition to being an option for leisure, production, labor and political-cultural participation for peripheral youths, can be understood as a powerful literacy agency (KLEIMAN, 1995). Based on our experience in a peripheral soirée, Sarau V (Viral), held in the city of Nova Iguaçu, metropolitan region of the state of Rio de Janeiro, idealized and organized by coauthor Janaina Tavares, we weave a narrative by a 'double authorship' in two distinct textual genres (BAKTHIN, 1997), which we call scene-writing and back-writing (GOFFMAN, 1985). Based on the field of literacy studies (STREET, 2001), we argue that the practices of the Sarau V show a multisemiotic and multisensory writing (MILLS, 2016) that denaturalizes hegemonic scalar projections (CARR; LEMPERT, 2016), re-territorializes urban spaces (GUATTARI; ROLNIK, 2010) and claims the right to the city (HARVEY, 2016).

Keywords: Literacies; peripheral youth; right to the city.

\section{"Os saraus são as bibliotecas sonoras das periferias": uma narrativa sobre letramentos e o direito à cidade}

\begin{abstract}
Eu amo a rua. Esse sentimento de natureza toda íntima não vos seria revelado por mim se não julgasse, e razões não tivesse para julgar, que este amor assim absoluto e assim exagerado é partilhado por todos vós. Nós somos irmãos, nós nos sentimos parecidos e iguais, nas cidades, nas aldeias, nos povoados, não porque soframos, com a dor e os desprazeres, a lei e a polícia, mas porque nos une, nos nivela e agremia o amor da rua.
\end{abstract}

A Rua. João do Rio.

As produções culturais periféricas, além de serem uma opção de lazer, de produção, de trabalho e de participação político-cultural para as juventudes que habitam territórios que margeiam centros geográficos, econômicos e urbanos, podem ser entendidas também como uma poderosa agência de letramento (KLEIMAN, 1995). Nos saraus, nos slams ou batalhas de poesia, nos bailes funk e nas diversas manifestações do hip hop (break, grafite,rap) circulam vários tipos de escritas que desafiam uma visão racionalista, economicista e individualista (SCOLLON; SCOLLON, 1995) sobre os letramentos. Considerando as nossas vivências, em um sarau periférico, chamado Sarau V (de Viral), realizado na cidade de Nova 
Iguaçu, região metropolitana do estado do Rio de Janeiro, idealizado e organizado por Janaina Tavares,tecemos uma narrativa multissemiótica constituída por uma 'dupla autoria' -resultante de um diálogo entre orientadora/orientanda, mas também da interação entre vozes ${ }^{3}$ que ocupam distintos espaços de observação e atuação nessa produção cultural ${ }^{4}$.

Tomamos de empréstimo as metáforas 'bastidor' e 'cena' de Erving Goffman (1985) como uma forma de organizar a nossa construção textual, pois assim como Goffman argumenta que a definição das situações cotidianas não são uma prerrogativa individual, mas um "trabalho de equipe", entendemos que este artigo é também um tipo de ação escalar coletiva, ou melhor, uma perspectiva de equipe que se constrói permeada por duas formas de linguagem situadas em locais e gêneros discursivos diferentes: uma escrita-

\footnotetext{
${ }^{3}$ Utilizamos vozes sociais como distintas posições sócio-históricas que comparecem em textos (cf. BLOMMAERT, 2008)

${ }^{4}$ Enquanto Janaína Tavares pode ser compreendida como um ator do evento social em análise, uma vez que é a produtora do Sarau, Adriana Lopes, ainda que tenha participado de uma das edições do Sarau, ocupa um espaço de analista.
}

bastidor, que segue um gênero discursivo acadêmico teorizando as práticas; e uma escrita-cena composta por fotografias e por pequenos fragmentos que chamaremos de cartas, que foram escritas em prosapoética na primeira pessoa $\mathrm{e}$ endereçadas à rua, trazendo as memórias das cenas vividas. Isso não quer dizer que essas escritas possam ser compreendidas de forma separada, tampouco que a escrita/cena seja objeto de análise da escrita/bastidor. Organizadas como gêneros discursivos distintos, ambas têm como objeto de reflexão as práticas de letramentos do Sarau V trata-se, portanto, de escritas que dialogam, se complementam e se contaminam, construindo uma perspectiva narrativa para a nossa dupla observação.

De saída, vale destacar que integramos grupos de interlocução e de pesquisa $^{5}$ que investigam sobretudo práticas de letramentos que

\footnotetext{
${ }^{5}$ As reflexões aqui apresentadas também são fruto do diálogo em grupos de pesquisa interdisciplinares, Oicult e CELeC, que reúnem pesquisadoras/es das áreas da cultura, da educação e da linguística que investigam as produções culturais periféricas e suas práticas de letramentos (cf. MAIA, 2017; LOPES, Adriana et al., 2017; SILVA, 2019; LOPES; FACINA; SILVA, 2019)
} 
LOPES, Adriana C.; TAVARES, Janaina. "Os saraus são as bibliotecas sonoras as periferias": uma narrativa sobre letramentos e o direito à cidade. PragMATIZES - Revista Latino-Americana de Estudos em Cultura, Niterói/RJ, Ano 11, n. 20, p. 51-68, março 2021. tem lugar em contextos nãoescolarizados, pois há um entendimento de que essas práticas possibilitam certa desconstrução e um alargamento das fronteiras daquilo que, tradicionalmente, foi entendido como leitura e escrita não só nas práticas pedagógicas escolarizadas, mas nos discursos hegemônicos que circulam em espaços de poder. Como enfatiza Roy Harrys (2000), repensar a escrita escolarizada e alfabética é, de alguma maneira, refletir sobre algo que está para além das práticas comunicacionais, já que, nas narrativas coloniais, o mundo moderno foi dividido, ranqueado e hierarquizado territorialmente, de acordo com critérios civilizacionais, medidos em função das práticas de letramentos dos grupos sociais.

A história recente de ocidentalização do mundo foi acompanhada pela difusão da escrita alfabética. Para Walter Mignolo (2000), a colonização foi um momento em que importava fornecer a escrita e a história para aqueles povos que, em uma perspectiva grafocêntrica e eurocêntrica, seriam considerados povos 'sem escrita' e 'sem história.' Em diálogo com os Novos Estudos dos
Letramentos (STREET, 2001), que compreendem a escrita como uma prática social atravessada por relações de poder, trazemos essa reflexão póscolonial por dois motivos. Primeiro, para mostrar como a disseminação da escrita não é a difusão de uma técnica neutra, mas está, intrinsecamente, relacionada às ideologias e aos processos de dominação dos povos. Segundo, porque entendemos que os sujeitos não são passivos diante desse movimento. Pelo contrário, nesse processo não só a escrita alfabética é modificada, como também a maneira pela qual essa passa a ser compreendida e utilizada.

Considerando a escrita alfabética como uma tecnologia de poder, algumas perguntas sobre escritas produzidas por sujeitos periféricos são norteadoras de nossas pesquisas e moldam as reflexões construídas neste texto. Uma questão cara para nós é compreender o que as pessoas produzem em termos de cultura e de letramentos em contextos não-escolarizados. Desse modo, com um olhar etnográfico ${ }^{6}$ observamos qual

\footnotetext{
${ }^{6}$ A postura etnográfica diante das práticas de escrita é colocada pelos Novos Estudos dos Letramentos (STREET, 2014). Já que a escrita não é uma técnica de valor universal,observá-
} 
LOPES, Adriana C.; TAVARES, Janaina. "Os saraus são as bibliotecas sonoras as periferias": uma narrativa sobre letramentos e o direito à cidade. PragMATIZES - Revista Latino-Americana de Estudos em Cultura, Niterói/RJ, Ano 11, n. 20, p. 51-68, março 2021. o movimento da escrita quando esta passa a ser uma tecnologia central na organização das práticas de pessoas que habitam as periferias brasileiras locais que, hegemonicamente, são imaginados como territórios marcados pela "carência", pela "falta" de cultura, pela "ausência" de educação e pelo iletramento. Tendo, então, essa reflexão em mente é que trazemos a nossa dupla experiência no Sarau V.

No ano de 2013, Janaína Tavares deu início ao primeiro sarau de artes integradas (audiovisual, teatro, dança, música etc.) que debateu política, direito à cidade, cultura e direitos humanos, em uma praça pública de Nova Iguaçu. Durante dois anos, o Sarau, que ocorria mensalmente, fomentou e movimentou uma nova geração de leitoras, de escritoras, de poetas, de atrizes e de fazedoras culturais, promovendo um contrafluxo da juventude na cidade. $O$ $\mathrm{V}$, como era carinhosamente chamado por suas frequentadoras, buscava chamar a atenção de certos grupos de jovens de que não era necessário deslocar-se da periferia para o centro

la envolve uma reflexividade crítica da pesquisadora para um fenômeno global que sempre adquire valores, sentidos e usos locais. em busca de diversão e de cultura (nesse caso, sair da região da Baixada Fluminense em direção à cidade do Rio de Janeiro). Aliás, podemos observar um movimento contrário: várias vezes $\mathrm{o} V$ contou com a presença de jovens habitantes de áreas centrais da cidade do Rio de Janeiro, não apenas como convidados especiais para debater sobre alguma temática, mas também como expectadoras que ali estavam para ouvirem o que a Baixada produz e tem a dizer. O Sarau V,durante seus dois anos de existência, estimulou a ideia de produção e de consumo de cultura dentro do próprio território, conectando pessoas de diversos locais com aquelas que escrevem e são escritas na/pela periferia.

Vale lembrar que "centro" e "periferia" não são conceitos essenciais, termos que apenas refletem ou descrevem, de forma neutra, os espaços físicos e urbanos das cidades. Em diálogo com os estudos da linguagem, Silva (2019), ao teorizar sobre os letramentos em periferias brasileiras, destaca como periferia é um conceito escalar, ou seja, são projeções simbólicas construídas por processos formais de 
LOPES, Adriana C.; TAVARES, Janaina. "Os saraus são as bibliotecas sonoras as periferias": uma narrativa sobre letramentos e o direito à cidade. PragMATIZES - Revista Latino-Americana de Estudos em Cultura, Niterói/RJ, Ano 11, n. 20, p. 51-68, março 2021.

significação e de distinção social. Vale lembrar que o conceito de escala, oriundo da geografia, relaciona-se com as formas de organização espaçotemporal da experiência humana e que, nos últimos anos, foi apropriado por diversos campos do saber. Desse modo, em consonância com debates da sociolinguística da globalização e da antropologia linguística (SILVA, 2019), entendemos que definir "centro" e a "periferia" como escala é assumir que as circunscrições desses espaços sociais são perspectivas (CARR; LEMPERT, 2016) socialmente interessadas e investidas por relações de poder e por disputas institucionais que definem as formas de segmentar, de separar, de territorializar e de dizer, logo de circular e de viver na cidade. Nas palavras de Silva, (2019, p.17)

A organização de uma escala sobre
esse espaço confere a ele
relevância, em condições e lutas
institucionais específicas. Escalas
são úteis para nos lembrar que
diferenças são acompanhadas de
hierarquias e disputas pelo poder
encaixadas na ação de
contextualizar.

Nesse sentido, vale lembrar o trabalho etnográfico de Érica Peçanha do Nascimento sobre um dos primeiros saraus na periferia da cidade de São Paulo, o Sarau da Cooperifa, idealizado e organizado pelo artista e poeta Sergio Vaz. A autora argumenta que a cultura de periferia não é algo dado, mas é produzida por ativistas e artistas por meio da junção de modos de vida, de comportamentos coletivos, de valores, de práticas, de linguagens e de vestimentas dos membros das classes populares situados nos bairros ditos periféricos.Desse modo, essa cultura fez emergir "novos sujeitos políticos" que publicizam discursos, demandas e práticas coletivas que estão relacionadas às esferas de produção e de consumo cultural. Nesse movimento, novos sujeitos aparecem na cena, tomam a palavra e a periferia é (res)significada. Segundo Nascimento (2011, p.11),

Favelados, periféricos, suburbanos,
marginais e marginalizados, que
sempre foram tema ou inspiração de
criações artísticas, passam de
objetos a sujeitos e esforçam-se para
transformar suas próprias
experiências em linguagem
específica. E tudo aquilo que um dia
faltou - acesso, infraestrutura, bens,
técnica, dentre outros - torna-se
matéria-prima para a estética que
está sendo edificada.

Podemos compreender, portanto, que nessa cultura periférica, a projeção escalar centro-periferia é questionada. De acordo com Carr e Lempert (2016), há modelos escalares 
LOPES, Adriana C.; TAVARES, Janaina. "Os saraus são as bibliotecas sonoras as periferias": uma narrativa sobre letramentos e o direito à cidade. PragMATIZES - Revista Latino-Americana de Estudos em Cultura, Niterói/RJ, Ano 11, n. 20, p. 51-68, março 2021. assim, a maneira como as juventudes experienciam o território e circulam nas cidades. Passemos, então, para as cartas, escritas/cenas do Sarau V.

\section{Escritas-cena: cartas de memória}

Foram dois anos e mais de vinte densamente povoada e diversa como a Baixada Fluminense(onde vivem mais de dezesseis milhões de pessoas, distribuídas em nove municípios)é, como diria a escritora Chimamanda Adichie (2010), vítima de uma "história única", pois essa é naturalizada nos discursos somente como um lugar homogêneo e carente de tudo (de saneamento, de esgoto, de cultura, de educação etc.) e, extremante, "temida pelo seu excesso de violência, simbolizada nas imagens de grupos de extermínio e seus assassinos sanguinários" (HERALDO HB, 2013, p.13).No entanto, como veremos nas escritas/bastidores de Janaina Tavares, tal projeção escalar é questionada, uma vez que a Baixada Fluminense transforma-se em periferia recontextualizada, ou melhor, periferia reterritorializada (GUATARRI; ROLNIK, 2010) - como local de habitação, de afirmação de identidades e de abundância de culturas e de letramentos, afetando, edições na rua."Primeiro Beijo", "Projetando o nosso amor","Rua, substantivo feminino", "Ação no território", "Pixo, logo existo", "Alma versada", "Quadrilha de ideias" e "Brincadeira é coisa séria" são os títulos de sete cartas endereçadas à rua que narram algumas edições. $O$ escritor e ativista Eduardo Galeano (2001) disse, "a memória guardará o que valer a pena. A memória sabe de mim mais do que eu; e ela não perde o que merece ser salvo". As edições narradas guardam o que mais valeu a pena e foram, afetuosamente, recontextualizada sem fotos e cartas escritas por uma das autoras deste texto e $\mathrm{MC}^{7}$ do Sarau, Janaina Tavares.

\footnotetext{
${ }^{7}$ Abreviação para Mestre de Cerimônia; uma abreviação que tem origem na cultura hip-hop para designar o rapper que canta as músicas; é utilizada também para nomear aqueles que apresentam o Sarau.
} 


\section{Carta 1}

\section{O primeiro Beijo}

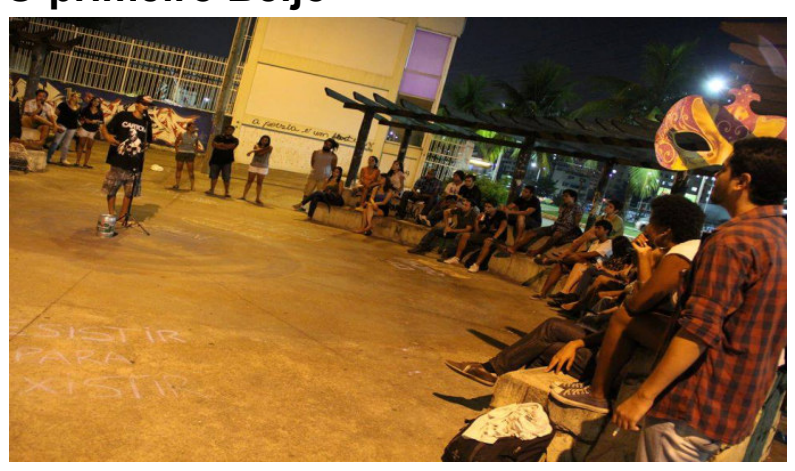

No dia 2 de Agosto de 2013, dei meu primeiro beijo na Praça dos Direitos Humanos, na Via Light, em Nova Iguaçu. Senti gosto de concreto, senti frio, senti eco. As palavras invadiam meus ouvidos como língua molhada e saíam da minha boca cortando as vias, atravessando o sinal, observando nas esquinas. Alguns foram brindar 0 nosso primeiro encontro. Com seus papéis, tablets, celulares, falavam para nós os poemas guardados nas gavetas da alma. Uns tiravam do bolso, outros do improviso. A gente mal conhecia aquelas pessoas, mas sabíamos que as veríamos outras tantas vezes. Estavam ali reunidos, um grande número de poetas que marcaram a história literária de Nova Iguaçu nos anos de 1980 e 1990. Eles andavam nos bares e nas esquinas, no tempo em que eu ainda chorava de cólica, babava com o crescer dos dentes e engatinhava pelo azulejo vermelho de casa. Eles já escreviam a cidade e eram escritos por ela.

\section{Carta 2}

\section{Projetando nosso amor}

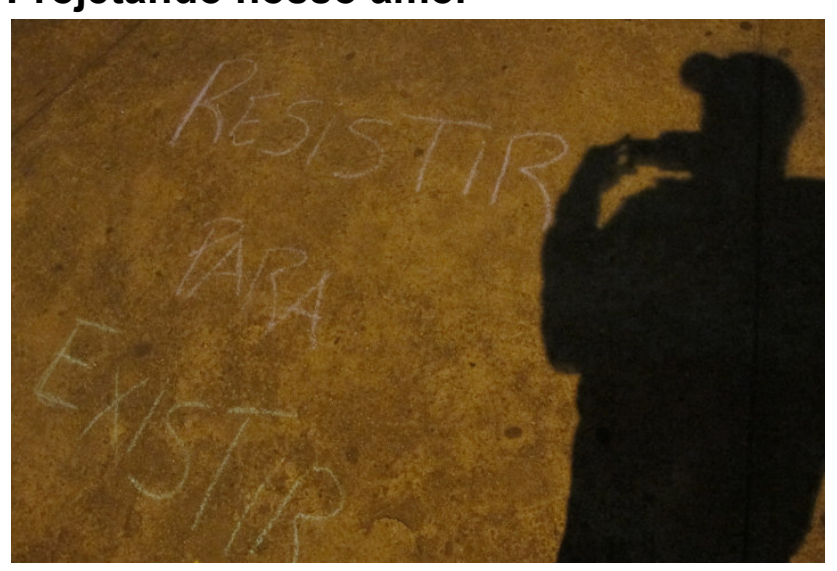

Naquela noite amarelada recebemos a primeira projeção na praça. O tema era carnaval de rua. Máscaras gigantes enfeitavam as entradas do palco urbano. Lembra das performances do poeta ciclista? Escrevi na entrada "Resistir para existir" ao invés de bem-vindos. A projeção de um curta metragem em preto e branco te desenha uma nova estampa. Te olho e suspiro ainda mais apaixonada, mais uma noite em que solidificamos o nosso amor. O jazz local embala nossa dança no final da noite. Te beijo de um jeito diferente. Você me abraça e me conforta. A lua 
LOPES, Adriana C.; TAVARES, Janaina. "Os saraus são as bibliotecas sonoras as periferias": uma narrativa sobre letramentos e o direito à cidade. PragMATIZES - Revista Latino-Americana de Estudos em Cultura Niterói/RJ, Ano 11, n. 20, p. 51-68, março 2021. celebra mais um encontro nas tuas veias e vias abertas.

\section{Carta 3}

\section{Rua, substantivo feminino}

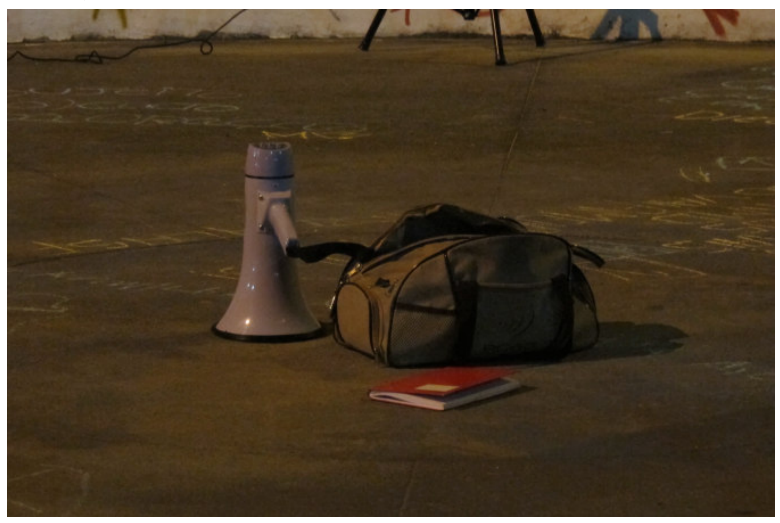

Nossa voz amplificada. Há noites que trazemos megafone e temos sempre o microfone aberto. Qualquer pessoa que queira, pode se expressar, se expandir e tomar a palavra no espaço público. A praça é um espaço predominantemente ocupado por homens: jovens, skatistas, roqueiros e a galera "legalize". O senhor palhaço conseguiu chamar a atenção de uns duzentos jovens com seus truques. Passado o chapéu, uma música regional foi fundo musical de uma ciranda ao redor de uma das antigas árvores do lugar. Girávamos no círculo do amor por você. Por tudo que você dança em nós.

\section{Carta 4}

\section{Ação no território}

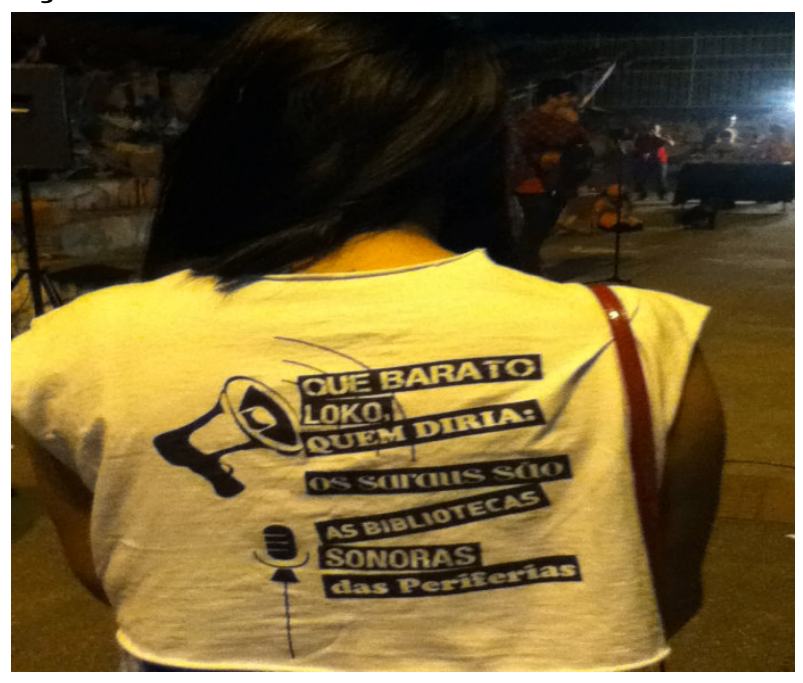

O brechó ambulante era o fundo do palco aberto. Um colorido, cheiro de guardado e estilos diferentes presos na arara de rodinha. O WG de Rua equilibra a bola de basquete na ponta do lápis, Zona Oeste presente! DJ, um jovem de Magé, fala da opressão policial que os secundaristas sofrem na Praça em que realizam o Sarau Corra que a Polícia Vem aí. Fomos obrigados a atravessar a rua em busca de um ponto de luz para ligar o equipamento de som. As cidades se encontram do outro lado, se comunicam, convergem e agem. É a partir do agir dentro do nosso território que o modificamos. É o pensar global e agir local. O V se preocupa com a cultura local, aquela que fala de nós e para nós, aquela cultura que é 
LOPES, Adriana C.; TAVARES, Janaina. "Os saraus são as bibliotecas sonoras as periferias": uma narrativa sobre letramentos e o direito à cidade. PragMATIZES - Revista Latino-Americana de Estudos em Cultura Niterói/RJ, Ano 11, n. 20, p. 51-68, março 2021. produzida e vivida por nós periféricos.

As luzes das grandes torres de energia na Via Light recebem meninas com poesias escritas em seu corpo. O corpo é o nosso primeiro território, os saraus são nossas bibliotecas. Tantos caminhos percorremos em nós.

\section{Carta 5}

\section{Alma versada}

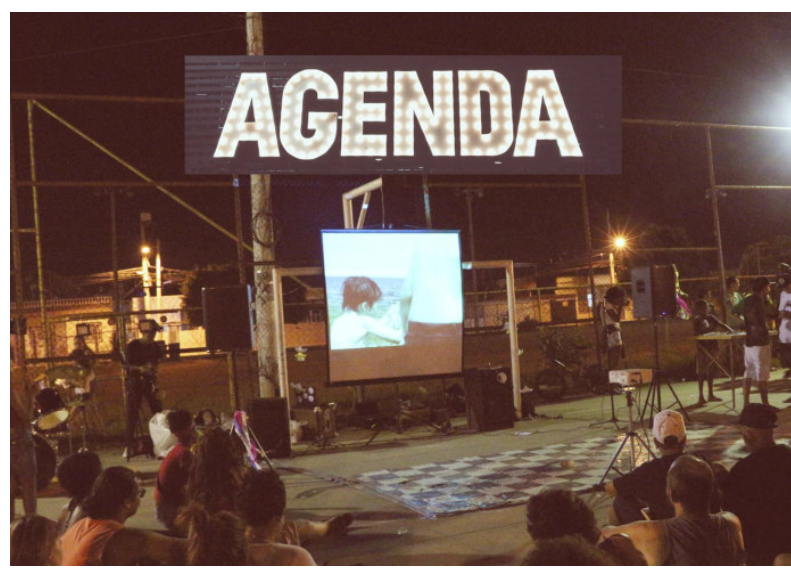

Exibimos um pedaço do documentário Luz, Câmera, PiXação, do Gustavo Coelho. De todas nossas memórias, não sei se eu te confessei, mas essa noite foi uma das minhas preferidas. Você que me ensinava tanto sobre representatividade, me conduziu a convidar pichadores e ex-pichadores pra contarem suas experiências. Alguns falaram da adrenalina, outros do vício em sentir o perigo, o frio da madrugada e o cheiro do Jet. Os que não mais pichavam, disseram que queriam ser vistos e chamar a atenção quando saía pra "pixar", pois é com " $\mathrm{x}$ " que se escreve a pichação ou o Xarpi do Rio de Janeiro. Era como se quisessem superar os seus limites. Se a cidade é projetada para os sufocar, eles iriam empurrar goela abaixo seus códigos secretos em seus rabiscos. O rap rolava nos intervalos nas batalhas de rima. Essa edição foi mágica, me lembra quando vejo uma pichação em um lugar tão improvável que penso: não tem como ir até lá sendo um humano, rs! Intelectuais, universitários, artistas, sentados numa praça ouvindo os marginalizados, os invisíveis, os expulsos. Fechamos o encontro com um violão acústico tocado por um ex-morador de rua. Te cheirei de um jeito diferente naquela noite. Te "pixei" em mim.

\section{Carta 6}

\section{Quadrilha de Ideias}

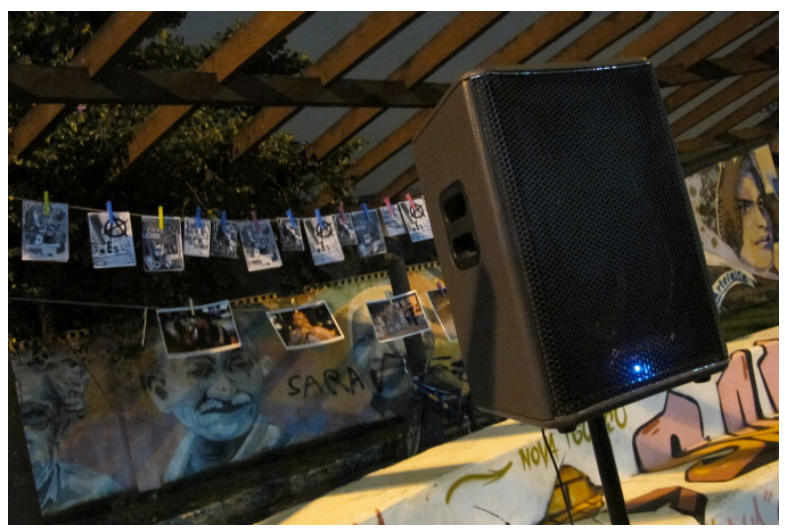


Enchemos a praça com lambe-lambe de poetas locais. Um grande varal com um acervo de cordéis coloria o lugar junto de fitilho, papel crepom e sorrisos das crianças que rabiscavam no chão com giz cor de rosa, amarelo, verde e azul. Severino declamava sua terra, seu sotaque e suas origens. O cristão e a candomblecista falam sobre respeito e intolerância religiosa. Alguns produtores locais falam da importância do $\mathrm{V}$ pra cidade e anunciamos a despedida da Praça dos Direitos Humanos. Levaram uma cachaça paraibana pra integrar na nossa mesa de doces típicos de São João. A panela com caldo de ervilha ainda estava quente. Era como se tivéssemos casadas. Eu e você, prontas para lua de mel: o Sarau $\mathrm{V}$ itinerante. Os convidados dançaram a dança da laranja e levaram livros do Moduan Matus de brinde. Fomos embora com a sensação de dever cumprido. Mas tinha um vazio do lado de dentro.

\section{Carta 7}

\section{Brincadeira é coisa séria}

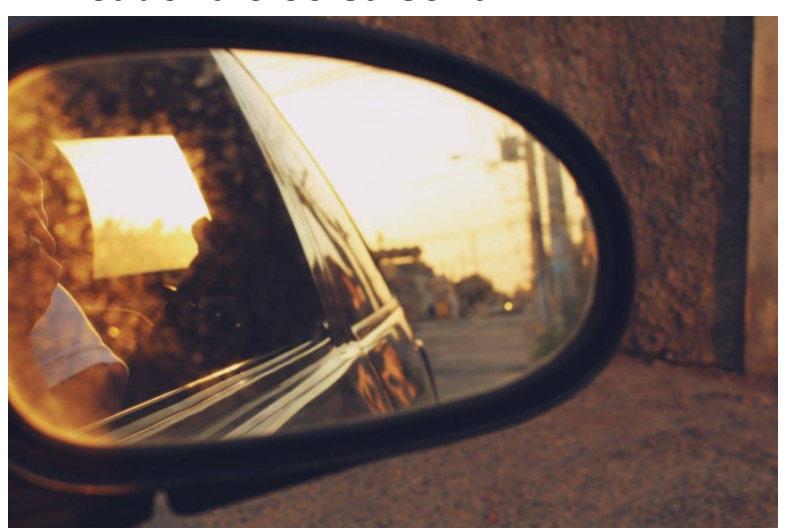

Depois de quase dois anos ocupando a Praça dos Direitos Humanos, entendemos que mesmo já estando numa cidade periférica, existe uma periferia dentro da periferia, que produz e precisa ser alcançada e ganhar visibilidade. Com isso, fomos para o Bairro Valverde, em que já acontecia a Batalha do Federa, produzida e mobilizada por adolescentes e jovens do bairro. Realizamos em conjunto a primeira edição itinerante do Sarau V. Era um novo ambiente, com outros ares, cores e sons. Quando cheguei, te olhei com um brilho nos olhos, depois de tanto tempo de namoro, as coisas entre nós esfriaram e precisávamos inovar. O sol estava se pondo lentamente, parecia pedir pra ser fotografado. Vi o movimento ao redor pelo retrovisor do carro. Os meninos fazendo a barba 
LOPES, Adriana C.; TAVARES, Janaina. "Os saraus são as bibliotecas sonoras as periferias": uma narrativa sobre letramentos e o direito à cidade. PragMATIZES - Revista Latino-Americana de Estudos em Cultura, Niterói/RJ, Ano 11, n. 20, p. 51-68, março 2021. ficarem roucas. A Anistia Internacional recruta uma meninada pra campanha Jovem Negro Vivo. Já é quase meianoite. É hora de voltar pra casa. Desproduzir. Guardar os fios, as tomadas, as caixas de som, as telas, o projetor e os livros. Começa a esfriar. Sinto uma batida na barriga. $\mathrm{Na}$ boca. Do estômago.

Escrita-bastidor:

letramentos multissensórios e o direito à cidade

Com as cartas endereçadas à rua e as fotos, encenamos fragmentos de uma pequena história sobre o Sarau V. Como já destacamos neste texto, o Sarau $\mathrm{V}$ muda a projeção escalar centro-periferia, pois traz a perspectiva daquelas/es que habitam os espaços considerados à margem. Antes da realização do Sarau, a praça era chamada por seus frequentadores de Praça do Coliseu, uma referência ao formato de sua construção. Localizada às margens de uma importante via da cidade, Via Light, a praça era o lugar de passagem, frequentada quase que, exclusivamente, por skatistas. No entanto, a praça foi batizada pela Prefeitura como "Praça dos Direitos Humanos", em memória às 29 vítimas 
LOPES, Adriana C.; TAVARES, Janaina. "Os saraus são as bibliotecas sonoras as periferias": uma narrativa sobre letramentos e o direito à cidade. PragMATIZES - Revista Latino-Americana de Estudos em Cultura, Niterói/RJ, Ano 11, n. 20, p. 51-68, março 2021. assassinadas em uma chacina ocorrida na cidade de Nova Iguaçu e de Queimados, ambas na região da Baixada Fluminense, no ano de $2005^{8}$. Porém, até a realização do Sarau V, esse nome não era utilizado para a designar tal espaço.

Vale lembrar que foi apenas quando Janaina Tavares foi à prefeitura pedir autorização para a realização da primeira edição do Sarau, que ela descobriu o nome de registro da praça. Porém, o nome direitos humanos era apenas um "simulacro teórico" que olha de cima e não se entrelaça aos fazeres espaciais do dia-a-dia (CERTEAU, 1994, p. 171). Aquele lugar era delimitado e enunciado como a Praça do Coliseu. Os letramentos do Sarau realizaram uma intervenção espacial ali, reescrevendo e colocando em prática o nome oficial."Se é a ação que qualifica o espaço" (CERTEAU, 1994, p. 171) foram as práticas de letramentos do Sarau que reterritorializaram a praça, colocando em prática o seu nome oficial. Guattari e Rolnik (2010) argumentam que a

\footnotetext{
${ }^{8} \mathrm{https}: / /$ www.brasildefatorj.com.br/2019/03/30/ maior-chacina-da-historia-do-rio-completa-14anos
}

reterritorialização é indissociável da desterritorialização. Trata-se de agenciamentos de humanos e de nãohumanos em que "a reterritorialização consistirá numa tentativa de recomposição de um território engajado num processo desterritorializante" (GUATTARI; ROLNIK, 2010, p. 388). Assim, o Sarau V desterritorializa a Praça do Coliseu, apenas como um lugar de passagem ou dos skatistas, projetando outra escala que reterritorializa o espaço como Praça dos Direitos Humanos.

Entendemos que esse movimento de reterritorialização realizado pelo Sarau V estabelece uma relação intrínseca entre os letramentos ali encenados e os direitos humanos. Para compreendermos essa relação, vale fazermos uma breve aproximação entre as práticas de letramentos do Sarau daquilo que o crítico literário, Antônio Cândido (1995), conceitua como sendo literatura. Para o escritor, a literatura (assim como toda e qualquer forma de fabulação - "todas as criações de toque poético, ficcional ou dramático em todos os níveis de uma sociedade" (CÂNDIDO, 1995, p. 188) - é um 
LOPES, Adriana C.; TAVARES, Janaina. "Os saraus são as bibliotecas sonoras as periferias": uma narrativa sobre letramentos e o direito à cidade. PragMATIZES - Revista Latino-Americana de Estudos em Cultura, Niterói/RJ, Ano 11, n. 20, p. 51-68, março 2021. direito humano, pois permitiria às pessoas (re)inventarem o cotidiano, seja como um maneira de dar "forma aos sentimentos para libertação do caos", seja como "um instrumento consciente de desmascaramento, pelo fato de focalizar as situações de restrição dos direitos, ou de negação deles, como a miséria, a servidão" (p.189).

Atentas às tensões entre ideais universais e as especificidades culturais, Silva e Palma (2018, p. 604) pensam os direitos humanos como "um corpo discursivo de disputas, de reivindicações e de aspirações" de populações vulneráveis ao redor do mundo. Alinhadas com essas autoras, entendemos que os letramentos do Sarau V são um corpo discursivo que reivindica a (res)significação dos territórios e $\mathrm{O}$ direito à cidade,reinventando a escrita alfabética universal de acordo com os fazeres e demandas locais. Como é narrada na escrita/cena, (re)territorializar a praça é ficcionalizar ${ }^{9}$ por meio de uma profusão de escritas multissemióticas (STREET, 2001) e

\footnotetext{
${ }^{9}$ Como nos ensina Geertz (1978), consideramos ficção "no sentido original de fictio- como algo construído, algo modelado" e não como um falseamento.
}

multissensórias (MILLS, 2016) - o varal de fanzines, a biblioteca sonora com seus amplificadores (do microfone ao megafone), as projeções audiovisuais, o giz no chão, o "pixo" (com X), o grafite e o corpo que dança.

Para refletir sobre essa diversidade de escritas como práticas de letramentos, lembraremos de debates recentes deste campo. Nos últimos quinze anos, os estudos dos letramentos foram afetados pelo que Mills (2016) chama de "virada digital", pois as práticas de escritas foram profundamente alteradas pelas transformação das mídias e das tecnologias, bem como pelas novas formas de comunicação e de interação. Ainda segundo Mills (2016), as tecnologias digitais forçaram as pesquisas a consideraram as dimensões sócio material e sensorial não como algo periférico ou complementar às escritas contemporâneas, mas como algo intrínseco às práticas. Se os Novos Estudos dos Letramentos destacaram a heterogeneidade de escritas e a multimodalidade dos textos (STREET, 2001; GEE, 1990; BARON; HAMILTON; IVANIC, 2000; KLEIMAN, 2006; ROJO, 2009) - ou seja, todo 
LOPES, Adriana C.; TAVARES, Janaina. "Os saraus são as bibliotecas sonoras as periferias": uma narrativa sobre letramentos e o direito à cidade. PragMATIZES - Revista Latino-Americana de Estudos em Cultura, Niterói/RJ, Ano 11, n. 20, p. 51-68, março 2021. texto é constituído por semioses verbais e não-verbais -, a virada digital dá ênfase à materialidade e a multissensorialidade situada e corporificada dos letramentos, ou seja, toda prática de escrita é uma prática corporal sinestésica composta e atravessada por uma profusão de matérias tangíveis. Em uma perspectiva semiótica semelhante, Kress (apud MENEZES, 2001, p.170) critica o "visualismo" e enfatiza a sinestesia na construção de significados:

\begin{abstract}
Maneiras diferentes de construir o significado envolvem formas diferentes de engajamento corporal com o mundo - isto é, não apenas através da visão (...) mas também através do tato, do olfato, do gosto, da sensação. (...) Essa habilidade e esse fato da sinestesia é essencial para que os seres humanos compreendam o mundo.
\end{abstract}

Desse modo, a ênfase sinestésica amplia as fronteiras do conceito ocidental sobre 'o que é' e 'como se' produz a escrita. Nas cartas à rua, são encenadas muitas sensações - do frio da madrugada com cheiro do Jet -, lembrando-nos que não é, apenas, a 'visão' o sentido engajado nos letramentos, o olfato também participa das práticas de escrita da praça. A foto que acompanha a carta "Ação no território" traz a foto de uma camiseta utilizada por uma jovem com a estampa em que se lê: o Sarau é a biblioteca sonora da periferia. Poderíamos dizer, então, que a biblioteca do $\mathrm{V}$ acentua a presença dos corpos e da audição em um espaço onde a leitura e a escrita em nada se aproximam das práticas que, tradicionalmente, imaginamos como aquelas pertencentes a uma biblioteca - espaço silencioso, onde se organiza e se esquadrinha tradição. Com Foucault (2009), poderíamos imaginar a biblioteca sonora como um "arquivo" em movimento, que está além dos livros da civilização selecionados como saberes sacralizados; uma biblioteca onde há um alarido de sons e uma pluralidade de vozes poéticas daquelas que, na perspectiva colonial, foram consideradas "sem-história" (FOUCAULT, 2009).

Além da multissensorialidade, 0 Sarau nos permite refletir sobre a dimensão sócio material e o agenciamento dos objetos nas práticas de leitura e de escrita. Não estamos querendo dizer que objetos agem por si só, mas que eles são determinantes e têm um papel formativo na educação e nos letramentos (MILLS, 2016; DUSSEL, 2017). Na biblioteca sonora 
LOPES, Adriana C.; TAVARES, Janaina. "Os saraus são as bibliotecas sonoras as periferias": uma narrativa sobre letramentos e o direito à cidade. PragMATIZES - Revista Latino-Americana de Estudos em Cultura, Niterói/RJ, Ano 11, n. 20, p. 51-68, março 2021. do $\mathrm{V}$, há uma profusão de coisas - o megafone, o microfone, os alto-falante, o projetor, o giz, a caneta, o jet -que compõem a cena, a identidade das autoras e as formas de interação e de ação coletiva,pois como encenamos na carta "Rua, substantivo feminino", o microfone é aberto, qualquer pessoa que queira pode se expressar, se expandir e tomar a palavra no espaço público.

\section{Palavras Finais}

Fundamentada por uma prática pedagógica dialógica que durou quase todo o período de graduação em Letras da, então, estudante Janaína Tavares, construímos esta pequena narrativa do Sarau V. Compreendemos que essas práticas são experiências de extrema importância não só para os campo de investigação e de estudos dos letramentos, como também para a própria escola. Compreender e valorizar as práticas das juventudes periféricas que têm lugar fora da escola, principalmente, em territórios imaginados hegemonicamente como desertos culturais e de letramentos, é fundamental para que possamos construir pedagogias mais sensíveis às formas pelas quais as estudantes mobilizam recursos simbólicos e materiais específicos no interior de suas comunidades, estabelecendo pontes (e não muros) entre saberes e letramentos.

Em nossa polifonia textual, endereçamos cartas à rua e terminamos este texto, lembrando da etimologia de tal palavra, pois entendemos que ela aponta não só para a relevância desses saberes, mas para as sementes de esperança presentes nos letramentos das juventudes dos subúrbios, das favelas e das periferias. No dicionário Oxford encontramos a seguinte referência à etimologia da palavra rua: do latim 'ruga' (uma 'dobra' na pele em forma de 'sulco'). Isso porque as ruas na Roma Antiga tinham a função primária de servir como canais de escoamento das águas das chuvas. Subsidiariamente, as ruas funcionavam também como via de circulação. Nas cidades modernas, porém, a prioridade da rua inverteu-se. Aproveitamos aqui a ideia de 'dobra' e de 'sulco' como um traço que persiste na rua das cidades modernas; um traço que nos lembra que a rua não é o local, apenas, de circulação, ela é também um certo percurso de fuga 
LOPES, Adriana C.; TAVARES, Janaina. "Os saraus são as bibliotecas sonoras as periferias": uma narrativa sobre letramentos e o direito à cidade. PragMATIZES - Revista Latino-Americana de Estudos em Cultura, Niterói/RJ, Ano 11, n. 20, p. 51-68, março 2021. dos mapas hegemônicos; um percurso onde a juventude ficcionaliza e "sonha acordada" (BLOCH, 2006) com um futuro melhor; uma dobra de esperança onde nascem e florescem letramentos periféricos que, em alguma medida, transformam coletivamente as vidas precárias das cidades, reterritorializam as projeções escalares desiguais e reivindicam 0 direito à cidade que, como coloca o geógrafo e ativista David Harvey (2012), é mais do que a liberdade individual para acessar os recursos urbanos: é o direito de mudar a nós mesmos, mudando a cidade. Trata-se da liberdade de "recriar nossas cidades e a nós mesmos - um dos mais preciosos e dos mais negligenciados dos nossos direitos humanos" (p.74)

\section{Referências bibliográficas}

BAKHTIN, M. Estética da criação verbal. São Paulo: Martins Fontes, 1997.

BARTON, D.; HAMILTON, M.; IVANIC, R. (orgs.) Situated Literacies: Reading and wrintng in context. Londres: Routledge, 2000.

BLOCK, E. O Princípio da Esperança. Vol.III. Rio de Janeiro: Contraponto, 2006.

BLOMMAERT, J. Grassroots literacies: Writing, identity and voice in Central
Africa. London: Routledge, 2008.

CANDIDO, A. O direito à literatura. In: Vários Escritos. 3. ed. rev, e ampl. São Paulo: Duas Cidades, 1995. p. $235-263$.

CARR, E.; LEMPERT, M., (orgs.). Scale: Discourse and Dimensions of Social Life. Berkeley: University of California Press, 2016.

CERTEAU, M. de. A invenção do cotidiano. Vol. 1: Artes de fazer. Petrópolis: Vozes, 1994.

CHIMAMANDA, A. O perigo de uma história única. 2010. Disponível em: https://www.geledes.org.br/chimamand a-adichie-o-perigo-de-uma-unicahistoria/. Acesso em: 04 set. 2020.

DUSSEL, I. Sobre a precariedade da escola. In: LARROSA, J. Elogio da escolar (org.) Belo Horizonte:Autêntica Editora, 2017. p. 87-112.

FOUCAULT, M. Outros Espaços. In: Foucault, M. Estética. Literatura, pintura, música e cinema. Rio de Janeiro: Forense Universitária, 2009.

GALEANO, E. Dias e Noites de Amor e Guerra. São Paulo: L\&PM, 2001.

GEE, J. Social Linguistics and literacies. Ideologies in Discourses. Hampshire: The Flamer Press, 1990.

GEERTZ, Cl. Interpretação das Culturas. Rio de Janeiro, Zahar, 1978.

GOFFMAN, E. A representação do eu na vida cotidiana. Petrópolis: Vozes, 1985.

GUATTARI, F.; RONILK, . Micropolítica: cartografias do desejo. Rio de Janeiro: Vozes, 2010.

HARRYS, R. Rethinking Writing. London: Continuum, 2000.

HARVEY, David. O Direito à cidade. Lutas Sociais, São Paulo, n.29, p.73- 
LOPES, Adriana C.; TAVARES, Janaina. "Os saraus são as bibliotecas sonoras as periferias": uma narrativa sobre letramentos e o direito à cidade. PragMATIZES - Revista Latino-Americana de Estudos em Cultura, Niterói/RJ, Ano 11, n. 20, p. 51-68, março 2021.
89, jul./dez. 2012. Disponível em: https://edisciplinas.usp.br/pluginfile.php /272071/mod_resource/content/1/david

harvey $\% 20$ direito $\% 20 a \% 20$ cidade $\% 20$ .pdf. Acesso em: 4 set. 2020.

HB, HERALDO. O Cerol fininho da Baixada. Histórias do cineclube Mate com Angu. Rio de Janeiro: Aeroplano, 2013.

KLEIMAN, A.; ASSIS, Juliana. (orgs.). Significados e ressignificações do letramento: desdobramentos de uma perspectiva sociocultural sobre a escrita. Campinas: Mercado de Letras, 2016.

KLEIMAN, Angela B. Introdução: Modelos de letramento e as práticas de alfabetização na escola. In: KLEIMAN, Angela B. (org.). Os significados do letramento: uma nova perspectiva sobre a prática social da escrita. Campinas: Mercado de Letras, 1995. p. 15-61.

KRESS, G.; VAN LEEUWEN, T. Reading images: the grammar of visual design. Nova York: Routledge, 1996.

LOPES, Adriana; FACINA, Adriana ; SILVA, Daniel. Nó em Pingo d'água. Sobrevivência, Cultura e Linguagem. Rio de Janeiro: Mórula; Florianópolis: Insular, 2019.

LOPES, Adriana et al. Desregulamentando dicotomias: transletamentos, sobrevivências, nascimentos. Trabalhos em Linguística Aplicada, Campinas, v. 56, n. 3, p. 753-780, 2017.

MAIA, Junot. Fogos digitais: Letramentos de sobrevivência no Complexo do Alemão/RJ. Tese (Doutorado em Linguística Aplicada). Universidade Estadual de Campinas, Campinas, 2017.
MENEZES DE SOUZA, Lynn Mario. Para uma ecologia da escrita indígena: A escrita multimodal kaxinawá. In: SIGNORINI, Inês (org.). Investigando a relação oral/escrito e as teorias do letramento. Campinas: Mercado de Letras, 2001. p. 167-192.

MIGNOLO, W. D. Local histories/ global designs: Coloniality, subaltern knowledges and border thinking. Princeton: Princeton University Press, 2000.

NASCIMENTO, E. P. do. É tudo nosso! Produção Cultural na periferia paulistana. Tese (Doutorado em Antropologia). Universidade de São Paulo, São Paulo, 2011.

RIO, João do. A rua. In: $A$ alma encantadora das ruas. São Paulo: Companhia das Letras, 2008.

SCOLLON, R.; SCOLLON S.W. Intercultural communication. Oxford: Blacweel, 1995. 